\title{
Distance education: advantages and disadvantages of the point of view of education and society
}

\author{
Educação a distância: vantagens e desvantagens do \\ ponto de vista da educação e da sociedade
}

\author{
Mayra Martins Santana de Oliveira \\ Graduada em Administração pela Universidade Federal de Uberlândia \\ - UFU, Faculdade de Gestão e Negócios - FAGEN. \\ Servidora da Prefeitura Municipal de Uberlândia - Uberlândia - MG - Brasil \\ mayra.mso.udi@gmail.com
}

\author{
Antonio Sergio Torres Penedo \\ Doutor em Engenharia de Produção pela Universidade Federal de São Carlos - UFSCAR \\ Docente efetivo do Programa de Pós-Graduação em Administração (PPGA) da Universidade \\ Federal de Uberlândia - UFU, Faculdade de Gestão e Negócios - FAGEN - Uberlândia - MG - Brasil \\ drpenedo@gmail.com
}

Vinícius Silva Pereira

Doutor em Administração pela Fundação Getúlio Vargas - FGV Docente efetivo do Programa de Pós-Graduação em Administração (PPGA) da Universidade Federal de Uberlândia - UFU, Faculdade de Gestão e Negócios - FAGEN - Uberlândia - MG - Brasil viniciuss56@gmail.com

\begin{abstract}
This article aims to identify the main advantages and disadvantages of distance education for both students and the educational enterprise. The methodological procedure chosen was an exploratory case study aiming at an analysis of how effective this modality can be in relation to other traditional forms of teaching. In the course of the research it was possible to identify that the main advantage for the institution is the increase in the number of students attended. From the student's point of view, the main advantage is the flexibility offered by distance learning courses. It is possible that the distance modality continues to grow steadily, but it still seems utopian to say that at some point in the history of education, face-to-face teaching will become obsolete and thus be totally replaced by EAD. Not all students have the profile required to enter a distance learning course.
\end{abstract}

Keywords: Distance education. Business. Educational Technologies.

Resumo: Este artigo pretende identificar as principais vantagens e desvantagens da educação a distância, tanto para estudantes, como para o empreendimento educacional. 0 procedimento metodológico escolhido foi o estudo de caso exploratório visando uma análise do quão eficaz pode ser essa modalidade em relação às demais formas tradicionais de ensino. No decorrer da pesquisa, foi possível identificar que a principal vantagem para a instituição é a ampliação da quantidade de alunos atendidos. Do ponto de vista do discente, a principal vantagem consiste na flexibilidade oferecida pelos cursos ministrados a distância. É possível que a modalidade a distância permaneça em crescimento constante, mas ainda parece utópico dizer que em algum momento da história da educação, o ensino presencial venha a se tornar obsoleto e, dessa forma, seja totalmente substituído pelo EAD. Nem todos os alunos possuem o perfil necessário para ingressar num curso a distância.

Palavras-chave: Educação a distância. Negócios. Tecnologias Educacionais. 


\section{Introduction}

In the current scenario experienced, the search for information, rapidity, flexibility, and quality is unceasing. For this reason, both companies and professionals have sought ever more intensely to specialize and adapt to the market required standards. It is in this scenario that today you can come across the increasing range of courses offered at a distance, which are the type of education called distance education or distance learning.

Even with all the requirements encountered by professionals to perform their duties and achieve their place in the sun, people still find it difficult to find the necessary expertise due to the impossibility of attending a classroom course, is the lack of time, by distance or even by the unwillingness to be in the classroom regularly.

Taking advantage of these mishaps plaguing prospective students, educational institutions then saw in this new niche market a lucrative opportunity to undertake and invest.

Distance learning is increasingly present in the current education and thus emerge every year several educational institutions with the promise of distance education quality. There are institutions like the DEAC Distance Education Accrediting Commission, which have the sole function of credit quality educational institutions. The DEAC was founded in 1926, in the United States, to promote the quality of education and ethical practices for distance education mode. She created and regulated standards and accreditation procedures that seek to examine and approve educational institutions the distance.

DEAC is recognized by the US Department of Education as an accrediting institution and has the objective of ensuring a high standard of education in educational institutions. Currently, more than 2 million US students studying in institutions accredited by DEAC.

Today are offered courses in distance education mode for various levels: training for work or popular science, literacy campaigns and also formal education at all levels and fields of the education system, which cover various topics and apparently there are the clientele for all of them. Thus, this study aims to identify the main advantages and disadvantages of distance education for both students and the institution as a teaching mode, as well as the line of business. 
This study also aims to answer the following question: has the distance education mode disadvantages and advantages over the traditional teaching method (in person) from the point of view of the method's effectiveness and the profitability of this branch of business?

Educational institutions designed to meet the highest possible demand of students, the most varied audiences and students seeking for flexibility and possibility to qualify without the rigidity found in conventional methods considered. These are the aspects presented in this article, and the research intention is only to present the advantages and disadvantages both for the institutions and for the audience.

\section{Theoretical review}

In this stage it will be exposed the theoretical knowledge on the subject of the Distance Education and its origin in the early twentieth century, which was acquired by the renowned authors of these areas works. Besides the scientific weight found in the bibliography chosen to support this work, it is also considered relevant to expose the contribution of each author cited in the understanding of the subject mentioned.

There are currently two types of education, namely the presence, also conventional call, to be used for centuries and distance, more recent, but has increased its acceptance every day. Distance education, known acronym to call this type of education is the way of learning which is established by the use of technologies that allow interaction between the student and the teacher, although they are in physical environments and different timelines (MORAN, 1997).

According to an article published in The Journal, a North American journal specialized in education, the distance education appeared in the year 1840, year in which Sir Isaac Pitman had the idea of creating professional shorthand writing courses by correspondence. The concept was so successful that within a few years the education programs were already available in the UK, Germany, USA and Japan. In 1900, the first education department by correspondence appeared at the University of Chicago, and in 1911 it appeared in Australia, at the University of Queensland, in the Department of Foreign Studies. 
At the end of the 70s, the Open University, located in the UK, has initiated a development phase in distance education, which sent studying materials to its students, such as texts and audio and video, but also completed the study of radio and television broadcasts. In addition, tutors had telephone sessions with their students in order to ensure quality learning. Over the next two decades, the Open University has already had four open universities in Europe and more than 20 around the world.

In the United States, the first institution working with distance learning was the New York State's Empire State College (NYSE) in 1971. According to BIZHAN (1997), NYSE aimed to make higher education more accessible to students who were unable to attend classes on college campuses. The created program provided the entry of several students who did not have the requirements for entering in a traditional university. During this time, professors Charles Wedemeyer and Gayle Childs studied and were responsible for the advancement of research in distance education, which enabled the national and international growth of this type of education.

This type of education has gradually shown its intense increasing relevance because of its social bias, the inclusion point of view brought by the flexibility of the methodology used to those who hitherto could not attend educational institutions for lack of time availability or by the distance of the same, it brings the possibility of access to students who were outside the universities and other institutions, as argued by Preti (1996):

The growing demand for education, not only due to population growth and, above all the struggles of the working classes by access to education, to learn socially produced concurrently with the development of scientific and technological knowledge is demanding changes in the level of function and structure of school and university (PRETI, 1996).

This inclusion becomes more apparent because distance education enable students to establish their own study schedule, and the feasibility of this is provided by classes taught via the internet, most of the time, and through other media. The learner autonomy in the face of distance education methodology makes it possible that it has a chance to join various categories of courses such as graduation, graduate, technical courses, vocational and further training (MAIA; MATTAR, 2007). 
Another striking feature of distance education is the presence of tutors, which act as teachers in the learning process. The tutor responsible for mediation must take place between teacher-student and student-student. According to Perrenoud (2000), more than simply teaching the tutor's role is to get the student to learn, and it is extremely relevant.

As in any line of business, there are several problems that must be faced by students and educational institutions when it comes to distance education. According Valentine (2002), the problems in distance education are of internal and external order and include among them: 1) The quality of education itself, which is also a factor to be overcome in traditional education; 2) The hidden costs, which often are not classified correctly and may generate future problems; 3) Misuse of technology, and this problem is relevant to educational institutions and students; 4) The attitudes of teachers, who cannot adapt to the ways of teaching required by distance education and 5) The attitudes of students, who must be more committed than the students of traditional teaching.

Besides the aspects related to education and the effectiveness of this type of education, it is also interesting to note the distance education from the perspective of the line of business and entrepreneurship.

Baron and Shane (2007) define entrepreneurship as a business area aimed at innovation, whose actions are performed by specific individuals, which seek to identify means to put their ideas into practice by identifying an opportunity. In addition, the entrepreneur should be equipped with skills to manage the new business and project.

Entrepreneurship is now socially better accepted and being an entrepreneur is an option respected by the population. The media also contributes positively to this social dynamic, particularly for the attention and prominence it gives to successful cases, such as cases of leaders and entrepreneurial spirit that some people manifest. Thereby promotes the enterprise, making it a socially acceptable option. (FERREIRA; SANTOS; SERRA, 2010, p. 18).

Entrepreneurship education is growing and it is very important for the continued development of current modes of teaching and Education Entrepreneurs is a community that believes that. The Education Entrepreneurs is a global and 
diversity community that has a photo enhancing the quality and results of education from the leverage entrepreneurship in education. It was founded by the Bill \& Melinda Gates Foundation and assists entrepreneurs who wish to invest in education, through a set of programs that help in creating your business by creating learning events, providing materials that deal with the subject and global network of community leaders who help in the development of this type of business.

As seen, more and more increases the number of projects in education, and this fact is even more remarkable in the distance education mode. This is because today the low-income people have entered the labor market, which ultimately enable a series of new business. Thus, the demand for the formation of new professionals as well as retraining for those who crave a replacement market has been growing. It is in this favorable wave that several entrepreneurs decided to invest in distance education and how profitable this business is to allocate investments.

However, the idea that distance education is more cost-effective than traditional teaching is not an unanimity among the subject experts. According to Dr. Lenn Annetta (2004), from the State University of North Carolina (USA), administrators of educational institutions are investing all their resources in distance education to control the overall institutional costs, however, such an attitude is risky. They believe that distance education costs are lower than traditional education costs, but due to high wear and high dropout rate in this mode, the cost per student ends up being the same or even more than traditional teaching costs. According to analyses carried out, the dropout rate in distance education reaches $35 \%$ of students, while in the traditional teaching that content is only $20 \%$. If calculated all costs in distance education, as the cost of time, experience, the necessary technology, among others, the modality of distance education, highquality being, will have the same or higher cost per student of physics school.

According to Litwin (2001), the development of distance education contributed to the implementation of various aspects of education, such as training courses, job training or popular science, literacy campaigns and also formal education at all levels and fields of education system. Such flexibility in this mode favors more investment in this sector, because the educational institution has enough possibilities in case there is the need to adapt to market changes.

In this respect it is possible to note that distance education has emerged as a way of adapting to a new scenario in which it was realized that this trend was needed in order to meet a large but untouched demand: people who did not attend 
the face to face or presence courses for various reasons, including lack of time. According to Covey (2002), to anyone reaches the long-awaited adaptation for an organization to change, it is essential that this bid up all its flexibility and speed, because if professionals and companies are able to fit in a quick way, more time will have to adjust to the consequences triggered.

According to Caldas and Amaral (2002) it is necessary to learn to project the future and prepare for it, but the instability brought by this adjustment period eventually trigger a climate of insecurity in people. This statement may be sufficient to explain why so many people still strongly refute the distance education mode and judge negatively their effectiveness.

\section{Materials and methods}

We used the qualitative research method to produce this article and to analyze data because, as emphasized by Neves (1996), this differs from quantitative research at several points, for example, in the matter of following rigorously a previously established plan (based in defined assumptions and variables that have an operational importance). Qualitative research seeks not enumerate or measure events throughout its development and therefore does not enjoy statistical instruments. And still:

[...] Part of issues or focus of broad interests, which will define as the study progresses. It involves obtaining descriptive data about people, places, and interactive processes through direct contact with the researcher studied the situation, trying to understand the phenomena according to the subject's perspective, that is, the participants studied the situation. (GODOY, 1995, p. 58).

To achieve the proposed objective, it was used the literature of various scholars and researchers on Distance Education providing data collection through the in-depth study by the observation of concepts and opinions. It has also conducted a survey of the main institutions currently working with the subject, and some to evaluate the quality of teaching and other to encourage entrepreneurship in education. 
The chosen methodological procedure was the case study of the Distance Education. This exploratory case study sought to analyze how effective Distance Education can be compared to other traditional forms of education, from the point of view of education and the profitability of this line of business. The operation, according to Cooper and Schindler (2016), is particularly useful when researchers do not have a clear idea of the problems they will face during the study.

Assimilation behavior of a phenomenon is essentially an exploratory activity in which the main objective is to refine the idea of research to facilitate a wider search (KERVIN, 1992). Given this premise, the stage of data collection can be considered as a preliminary investigation as Emory \& Cooper (1991), constituting an essential method in conducting the research.

\section{Results analysis}

The distance education in Brazil has gone through some periods of stagnation due to lack of public policies in this sector. But there is also a remarkable breakthrough and successful path identified in this type of education.

Although distance education has been widely publicized and joined by a large portion of the population recently, in Brazil studies show that a little before 1900 it was possible to find ads in Rio newspapers which offered professional training via correspondence. However, the courses were not taught by institutions, but by private tutors. In the first twenty years of installation of this type in the country, teaching materials were distributed by mail and there was only a single level of education: vocational.

From 1923 on it was possible to find a learning program on the radio through private initiatives. In 1936 the institution had to give the station the Ministry of Education and Health for failing to meet the requirements of government. Soon after, several other institutions have decided to use the radio as well as learning binding way by setting the second half of Distance Education.

After that records of this type of education were found through what was called educational cinema, or also educational television, which exists until nowadays. With the advent of computers and the internet, however, the distance education was consolidated and began to expand worldwide. 
Several institutions have been offering distance learning courses via the Internet and the government, in turn, began to engage in the creation of laws that were applicable to Distance Education, whose effectiveness has gone through several periods of advances and setbacks, but that is in constant development. With the creation of the Open University of Brazil, whose definition can be understood as a consortium of public institutions of higher education, the access to higher education has become more popular and comprehensive.

This brief history of the development of distance education in Brazil tried to report in a fairly succinct and objective way more than a century of many events incurred in this sector, in order only to familiarize the reader about the importance of this study.

Through the methodology used was possible to identify the main strengths and weaknesses of this type of education for both the students and the institutions, which goes against the objectives and research problem mentioned at the outset, as follows below.

\subsection{Benefits for students}

Among the numerous advantages brought by distance education to students who use this modality to acquire knowledge and learning aims, a survey was done of the main, namely:

- Flexibility: many students look for distance education courses just because they cannot or do not want to expose themselves to the rigidity required in physical classroom courses. In this sense, the flexibility offered by distance mode is configured as a great advantage;

- Content availability: in most courses offered on site, the student attends classes that are offered only once and must write down and find other means for the given content is saved for future reference. In classes taught at distance, however, the content (usually recorded on video and audio) is available to the student for this review whenever necessary;

- Low cost: you can find on the market courses offers in various levels of education with much lower prices compared to the prices of traditional classroom courses; 
- Studying at home at any time you want: one of the factors that made the distance learning courses a success is exactly the fact that many students belonging to the target audience are already in the labor market and seeking thereof to qualify for new requirements. Accordingly, the lack of rigidity concerning time and study site may also characterize an advantage of the distance education for students from the standpoint.

\subsection{Disadvantages for students}

Although proved very advantageous, the distance education has also some biases contrary to learning. Among these was conducted a survey of some major, namely:

- You must have discipline: excessive flexibility can also represent a disadvantage to students who do not have enough discipline to be able to meet the required activities without the presence of a teacher to guide and supervise often;

- Do not take the teacher to take questions at the very moment they arise: in regular classes, students can have the opportunity to ask questions in the very moment they arise, while in distance courses that does not happen so easily, causing the student to save his questions for some future time meeting or another contact with tutors and teachers.

\subsection{Benefits for the educational institution}

Just as it is possible to identify negative and positive points of distance education from the point of view of the students who attend this type of education, such analysis was also performed according to the understanding of the institutions offering distance education in its various educational levels. Let's see first the main advantages detected:

- Lower cost: with distance education the institution can meet a wider audience of students using the same or fewer resources than traditional 
courses because the courses have a much larger number of students than in conventional classrooms, which ends up resulting in the decrease of the institution costs;

- There is no need for a physical space: the need for a physical space in classroom courses ends up generating a series of bureaucratic and costly processes, such as the need for business license and adjustments in physical facilities. The distance learning courses eliminate this need because the classes can be taught in virtual environments and other contacts that are relevant between student and institution can also be made between this and other non-personal means;

- A single class (video) serves to several classes: in the case of regular classes, the teacher must teach the same class for various classes at varying times. In distance education, the teacher and tutor have their lessons recorded in video format, for example, and the institution offers these videos to students, or the teacher teaches the content once. There is a need to record a new video just to update the content.

\subsection{Disadvantages to the educational institution}

Not only advantages were found, but also some weaknesses in relation to the viability of maintaining a course in a non-traditional way by the educational institutions:

- As for learning: the institution may end up losing its quality when in classroom mode the student has no opportunity to contribute more actively in the preparation of lessons. During conventional classes, students can contribute with their experiences, questions and considerations and thus make the class take different paths. While in the class distance, the student gets ready the teacher's speech and is unlikely to change the parameters set by the recorded lectures. Thus, it may be that the student stays with questions that are not taken at the exact moment they arise and still presents difficulties in terms of content, in many cases, the teacher does not even take notice; 
- Feedback student takes longer: in traditional classes the teacher gets feedback immediately, which does not happen in non-face classes. Therefore, the teacher takes longer to be aware if the student has obtained or not an efficient learning;

- Master of Education: the vast majority of teachers has both academic and professional experience, training to teach regular classes and are already used to this mode. This may generate some difficulty for teachers to teach classes of action at a distance;

- Cultural aspect: despite distance education has already been spread throughout the world and has an ever-increasing culture, Brazil is still very focused on classroom courses, and many students still have certain prejudice with this mode of teaching and believe distance courses are ineffective when compared to classroom courses.

\section{Discussion and considerations}

During the research, it was identified that the main advantage for the institution is precisely the fact that the distance learning enables service to a greater number of students, which would not be feasible to happen in the classroom mode if the intention was to maintain the quality of service. To the profitability of this type of education, it is necessary to pay attention to that. The overall costs of distance education are actually lower than those of traditional education, but the cost per student can be the same or even higher. The reason is correlated with the quality of the teaching provided. A poor-quality program will have a high dropout rate, and this will not reduce the costs if most of them are considered fixed. At the end, the cost per student will be greater than in traditional school, even if the total cost is not, due to the smaller number of students present and active in the distance education programs. Because of this, a constant assessment of the costs and the quality of such education should be carried out by educational institutions.

From the student's point of view, the main advantage is the flexibility offered by the distance courses, because there is no need for the frequency to the physical space (classroom) and thus the student can attend classes when still residing in a city or when in another city. The student also has the opportunity to develop activities in his own time, when he wants or can do it. 
It is possible that the distance mode remains constantly increasing, but it still seems utopian to say that at some point in the history of education, classroom teachings will become obsolete and thus be completely replaced by distance education. This is because not all students have the necessary profile to join a distance learning course, but rather have the need for physical space, with conventional classes so they can absorb the content.

For future studies, it is suggested to do a survey through questionnaires applied to students of distance education to enable them to assess and expose their judgment on the process. In another moment it still can be examined systematically whether there are discrepancies between the management of classroom courses and distance learning courses and in which mode remains the greatest challenges.

\section{References}

ANNETTA, Lenn. Investigating the relationship between cost, reach, and richness in distance education. Online Journal of Distance Learning Administration, v. 7, n. 4, 2004.

BARON, Robert A.; SHANE, Scott A. Empreendedorismo: uma visão do processo. Cengage Learning, 2007.

BIZHAN, Nasseh. A brief history of distance education. Occasional paper. Ball State University, 1997.

CALDAS, Ricardo Wahrendorff; DO AMARAL, Carlos Alberto A. Mudanças, razão das incertezas: introdução à gestão do conhecimento. Editora CLA, 2002.

COOPER, Donald R.; SCHINDLER, Pamela S. Métodos de pesquisa em administração. 12. ed. McGraw Hill Brasil, 2016.

COVEY, Stephen R. Liderança baseada em princípios. 2. ed. Elsevier Brasil, 2002.

EMORY, C. William; COOPER, Donald R. Business research method homewood: Irwin. Evans, J, 1991.

FERREIRA, Manuel Portugal; SANTOS, João Carvalho; SERRA, Fernando Ribeiro. Ser empreendedor, pensar, criar e moldar a nova empresa. São Paulo: Saraiva, 2010.

GODOY, Arlida Schmidt. Introdução à pesquisa qualitativa e suas possibilidades. Revista de administração de empresas, v. 35, n. 2, p. 57-63, 1995.

KERVIN, John B. Methods for business research. Harper Collins, 1995.

MAIA, Carmem. Mattar, João. ABC da EaD: a Educação a Distância hoje. São Paulo: Pearson, 2007. 
LITWIN, Edith. Educação a distância: temas para debate de uma nova agenda educativa. Porto Alegre: Artmed, 2001.

MORAN, José Manuel. Como utilizar a Internet na educação. Ciência da informação, v. 26, n. 2, 1997.

NEVES, José Luis. Pesquisa qualitativa: características, usos e possibilidades. Caderno de pesquisas em administração, São Paulo, v. 1, n. 3, p. 1-5, 1996.

PERRENOUD, Philippe. Utilizar novas tecnologias: 10 novas competências para ensinar. Porto Alegre: Artmed, 2000.

PRETI, O. Educação a Distância: uma prática educativa mediadora e mediatizada.

Cuiabá: NEAD/ IE -UFMT. 1996.

recebido em 9 ago. 2017 / aprovado em 31 jan. 2018

Para referenciar este texto:

OLIVEIRA, M. M. S.; PENEDO, A. S. T.; PEREIRA, V. S. Distance education: advantages and disadvantages of the point of view of education and society. Dialogia, São Paulo, n. 29, p. 139-152, mai./ago. 2018. Disponível em: <https://doi.org/10.5585/Dialogia.n29.7661>. 